\title{
Helmholtz and Goethe - Controversies at the Birth of Modern Neuroscience
}

\author{
Jürg Kesselring \\ Department of Neurology and Neurorehabilitation, Rehabilitation Centre Valens, Valens, Switzerland
}

\section{Key Words}

Hermann von Helmholtz - Neuroscience $\cdot$ Conservation of energy

\begin{abstract}
Hermann von Helmholtz (1821-1894), a great German scientist and philosopher, made his mark during the exciting twilight period from the Enlightenment and Romanticism to the beginnings of modern neuroscience and offered new perspectives through his work. His early inclination was for physics, which he found more attractive than purely geometric and algebraic studies, but his father was not able to make it possible for him to study physics, and so he studied medicine in order to earn a living. His lecture before the Physical Society in Berlin on July 23, 1847, 'about the conservation of the force' marked an epochal turn, even though his intention had been to deliver 'merely, some critical investigations and arrangement of facts in favor of the physiologists' as well as good arguments for the refusal of the theory of 'vitality'. Even though these new concepts were at first dismissed as fantastic speculation by some of the authorities in physics and philosophy of the day, they were enthusiastically welcomed by younger students of philosophy and the older men soon had to allow themselves to be persuaded that the effectiveness of vitality, though great and beautiful, is
\end{abstract}

actually always dependent on some source of energy. Helmholtz critically assessed Goethe as a physical scientist but he did not dispute his great importance as a poet.

Copyright $\odot 2012$ S. Karger AG, Basel

Hermann von Helmholtz (1821-1894), the eminent German scientist, had a great influence during the exciting times of transition from the Enlightenment to Romanticism and to the beginnings of modern neuroscience and provided new perspectives with his work. It is worthwhile to study the life and work of this man, who is regarded as one of the most influential scientists of the 19 th century. At the end of his schooldays in Potsdam he had already written an essay entitled: 'What impact does the study of history have to the scientific education of the mind?' In his obituary [1] it was stated:

Based on the concluding lecture at the Annual Meeting of the Deutsche Gesellschaft für Geschichte der Nervenheilkunde (www. dggn.de), Zürich, October 1, 2011 [Kesselring J: Die Geburtsstunde der modernen Neurowissenschaften: Hermann Helmholtz' Vortrag 'Über die Erhaltung der Kraft' am 23. Juli 1847 vor der physikalischen Gesellschaft zu Berlin. Schriftenreihe der Deutschen Gesellschaft für Geschichte der Nervenheilkunde. Würzburg, Königshausen \& Neumann, 2012, vol 18, pp 281-290].

\section{KARGER \\ Fax +41613061234 E-Mail karger@karger.ch} www.karger.com
(C) 2012 S. Karger AG, Basel 0014-3022/13/0693-0152\$38.00/0

Accessible online at: www.karger.com/ene
Prof. Dr. med. Jürg Kesselring

Department of Neurology and Neurorehabilitation

Rehabilitation Centre Valens

CH-7317 Valens (Switzerland)

E-Mail Juerg.Kesselring@ kliniken-valens.ch 
'To Helmholtz' undisputed professional success contributed a long series of papers and books. It has been said, that just as seven cities in antiquity competed for the name of Homer as their patron, so the seven sciences: mathematics, physics, chemistry, physiology, medicine, philosophy and aesthetics claimed Helmholtz to be one of their heroes and it is interesting to observe how early he perceived a comprehensive overview of the sciences which justifies this rhetorical statement. Judged by variety and importance he was probably never surpassed. He was assured admiration and respect of the whole civilized world during his lifetime. He received many honours [...], certificates and recognition addresses from learned societies spread all over the world, from Tomsk to Melbourne, recognizing the importance of his scientific work.'

At the Annual Meeting of the Royal Society in London on November 30, 1894 [2], the President, Lord Kelvin, gave an address to the members of the Society which remains interesting for us today more than 100 years later, not only because of the style, but also because of the priorities which an outsider, who was also an acclaimed specialist in his own field, saw in the achievements of one of the great scientists of the 19th century [3]: 'Science has suffered huge losses in the past year. In the list of the deceased, which I have read to you, you have heard the names of [...], all good, zealous in their lives and successful academic researchers who have contributed largely, which is important for the Royal Society, to increase the knowledge of nature.' He then proceeded [2]:

'A year ago, in my annual report I drew your attention to the experimental demonstration of Hertz about electrical waves that originally had been proposed to him in the development of an experimental issue of Helmholtz, as he was busy with research in the Physics Institute of Berlin in 1879. The book of Hertz describes his work on electric waves and is dedicated to Helmholtz "with gratitude". The student has died on the first day of the New Year, and within a year, he was succeeded by the master. I doubt if a single man can be qualified with the power that can provide knowledge and understanding so that he is able to speak adequately of the great and excellent work which von Helmholtz has provided in physiology, physics, and mathematics: but we all appreciate, to a certain extent, the services which he has rendered in biology thanks to his mathematical genius and his well trained skills in experimental physiological research. His early natural inclinations were towards physics, which he found more attractive than purely algebraic and geometric studies, but his father could not offer him the opportunity to study physics, so that he had to study medicine to earn a living, and he himself was by no means averse to study living rather than dead matter, onto which physics was limited.

I think we can now better understand how much the world has won by this fact, that this young man of great genius and strength, had to choose a practical profession. An early result, while still a student, was his careful investigation, on the theory of animal heat, and soon afterwards (1847) his great essay "on the conservation of force", conservation of energy, as we now call it, commu- nicated before the physical society of Berlin on July 23, 1847, about which he said in 1891: my aim "was simply to give some critical research and compilation of facts in favour of physiologists". His essay provides good arguments for the rejection of the theory of "life force", although dismissed by some of the physical and philosophical authorities at the time as a fantastic speculation, but was enthusiastically welcomed by younger students-philosophers and soon the older men had to be convinced that the actual effectiveness of "vitality", great and nice as it may appear, cannot be without a source of energy.'

In his essay 'Goethe und die Wissenschaften' ('Goethe and the sciences'), the German poet and physician Gottfried Benn (1886-1956) determines exactly - with poetic precision and accuracy - the beginning of mathematical and physical sciences, which radically moved away from natural philosophy and vitalist physiology after a few cleansing processes: 'The actual birth of this new world view was the 23 July, 1847, at the meeting of the Physical Society of Berlin, in which Helmholtz, inspired by Robert Mayer, demonstrated calculations and considerations for the problem of conservation of mechanical energy as a general law of nature. On this day the idea of full comprehensibility of the world was set in place' [4]. Helmholtz has, however, several times and on several occasions distanced himself clearly and unambiguously from the philosophical materialism of his time, yet it can be shown '(1) that in his philosophy of science he started from a metaphysical position which he could never quite shake off and (2) that his epistemology (theory of knowledge) as well as his reductionism have roots in the philosophy of German idealism. Although his philosophical thinking underwent a profound change, it remained embedded in an idealistic and metaphysical framework' [5].

In the introduction to his essay 'on the conservation of force', which followed the oral presentation, Helmholtz assumes that the phenomena in nature are the result of hidden causes. These hidden causes are equipped with the capacity to exert effects among each other and towards our sense organs. This property Helmholtz called 'force' and determines it as 'a constant force of motion'.

In order to understand nature science aims to reduce phenomena to immutable forces that attract and repulse each other, with an intensity which depends on distance. He wanted to logically resolve 'reality in two abstract ions: matter and force, resolve [...] the transient and perishable is to be seen as the manifestation of the everlasting, of the law' [5] (fig. 1).

Helmholtz [6] saw the risk of one-sided developments in his subsequent speech 'Das Denken in der Medizin' ('Thinking in medicine'): 


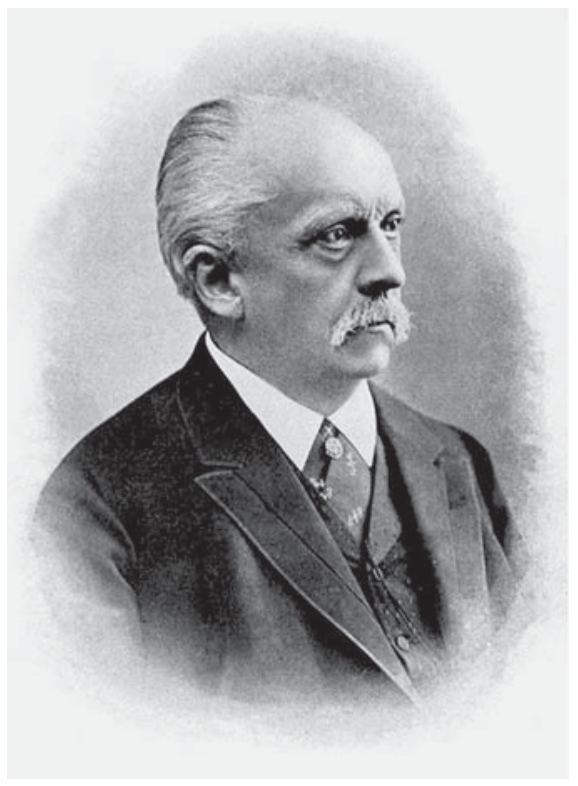

Fig. 1. Hermann von Helmholtz (1821-1894).

'Did we escape the views of "l'homme machine" of the materialist enlightenment as the Scylla of natural philosophy there is now the threat of the Charybdis of falling into pure materialism: as our generation has still suffered from the pressure of the spiritualist metaphysics, so the younger generation is running the risk of pure materialism.'

Helmholtz experienced and shaped a time that represents a turning point in history. It is, so to speak, a period when the swing between two different modes of looking at the world and of acting upon it reached its highest speed. This was recently described in detail by McGilchrist [7] in his monumental book The Master and His Emissary. The Divided Brain and the Making of the Western World on the basis of Nietzsche's condensed view of the history of philosophy. It correlates the different modes of different world views or actions in the world to the functions of the two hemispheres of the brain $[7,8]$.

Helmholtz wrote two essays on the scientific works of Johann Wolfgang von Goethe: 'Über Goethe's naturwissenschaftliche Arbeiten' [9] ('On Goethe's scientific works') and 'Goethes Vorahnungen kommender naturwissenschaftlicher Ideen' [10] ('Goethe's presentiments of emerging scientific ideas'). Both articles are concerned with the question of what is true and correct science in contrast to art in the context of Goethe's work in morphology, botany and optics. Goethe as a prose writer, but even more so as a poet, always confident of his own values and gifted with universal curiosity and broad, often visionary culture, was convinced that nature gave lessons about life which science had to interpret rather than just to submit itself to in the service of art. He sang praises about the 'deep harmony' of nature. Helmholtz' views on science and the concerns he expressed about Goethe reveal the details of the supposed dichotomy between art and science. The methodological limitations of the disciplines do not automatically follow from the definition of their projects and methods but their projects and practices are articulated in discourses and practices within specific political and cultural contexts that are often different from other practices and ideas [11].

In his early work on Goethe's scientific investigations, Helmholtz wrote: 'Instead of trying to investigate the phenomena of nature under certain definitions regardless of intuition, he is facing them, as he would look at a work of art that sooner or later would reveal his central idea to a sufficiently susceptible student' [9]. Helmholtz argued that Goethe's work is not really scientific, because he saw nature with the intuitive eye of the artist, which led to two inexcusable errors: (1) it fails to understand causal relationships and (2) it neglects to formulate clear and unambiguous theories. Science ought to be based on laws and generalized formulas which exactly specify the invariant causal relationships between events.

He advocated an 'experimental inter-actionistic' conception of science, starting with generalizations about experience and manipulation of variables in order to see what remained constant under different test conditions, then the refinement of the original hypothesis, leading to an exact expression of relations of well-defined groups of objects [11].

In his later essay 'Goethes Vorahnungen kommender naturwissenschaftlicher Ideen' ('Goethe's presentiments of emerging scientific ideas') Helmholtz took the view that artistic intuition is a passive process through which the artist could obtain general truths about macrocosmic experiences and he admitted that intuitions often are the first step in a scientific project. He even claimed that art was - apart and outside of science - another way and another manner of obtaining insight into the intricate workings of nature [10]. He argued that in this respect Goethe had anticipated some contemporary scientific theories, and characterized the work of the poet as a less accurate anticipation of his own theory of sensation and of the law of conservation of force. For Helmholtz, Goethe as a scientist had failed, not because his overly active, romantic will projected onto his depictions of nature, but rather because Goethe with his passive observational approach accepted nature just as given - that for Helmholtz was the root cause of Goethe's scientific weaknesses. The artist 
had taken the view that the truths of nature can simply be collected and interpreted by a sufficiently subtle mind.

Helmholtz felt an urge and a mission to topple natural philosophy with its pretense to authority and unconstrained speculative approach from its privileged position in German science and to put experimental science in its place. Against the evils of the philosophy of nature, he decreed practices designed to cultivate tireless patience, strict compliance with experimental methods and step by step argumentation, to make sure that rush and premature conclusions were avoided. It is only by carefully and patiently carrying out tests and by carefully accumulating evidence that efficient scientists can ever hope to raise a mere hypothesis to the status of a law.

Why was Helmholtz, one of the most respected scientists of his time in Germany, so much interested in the scientific research of Goethe, who himself claimed that he was in the first place a poet? It has been said [12]:

'The scientist in him prevented the destruction of the person in him: for his want for beauty and culture and his obvious desire to share his feelings [...] and for the development of scientific reasoning in contrast to metaphysics he found philosophy extremely important. He made the difference between the logical reasoning of the scientist against the poetic thinking of the poet, each of which having his own methodology and different objectives.'

Helmholtz has been described as 'the most benevolent figure of the 19th century and in him German warmth and nature and a fine physical intelligence at their best provided a welcome mix ...' [13].

Helmholtz realized that 'the poet very concretely may [...] contribute to the acquisition of knowledge thanks to the strength of his artistic intuition and his metaphorical visions' [from 12, p. 210]. He may be able to describe states of mind with a truthfulness which is inaccessible for philosophers or empirical scientists. Helmholtz also felt and experienced, like so many of his contemporaries (certainly in Germany), an inner conflict which is often quoted from Goethe's Faust I, verses 1112-1117:

'Zwei Seelen wohnen, ach! in meiner Brust,

Die eine will sich von der andern trennen;

Die eine hält in derber Liebeslust,

Sich an die Welt mit klammernden Organen;

Die andere hebt gewaltsam sich vom Dust

$\mathrm{Zu}$ den Gefilden hoher Ahnen.'

'Two souls alas! are dwelling in my breast; And each is fain to leave its brother.

The one, fast clinging, to the world adheres

With clutching organs, in love's sturdy lust;

The other strongly lifts itself from dust

To yonder high, ancestral spheres.'
Individual patients with their personal stories, hopes and fears have almost entirely disappeared from modern neuroscientific writings, where molecules, mice and genes are analyzed and rated much more highly than commitment to people, probably because they are easier to measure and manage. The swing between the hemispheres in McGilchrist's metaphor clearly tends towards the left hemispheric way of perception and action nowadays. A chemical laboratory in Helmholtz' times operated under the motto: 'God created the world by number, weight and measure' [14].

Helmholtz realized that artists work on a different level of consciousness than scientists and that truths revealed by artistic intuition were not accessible to scientific research in the same way. He emphasized that scientists and artists, using their own methods, were both in the position to acquire new knowledge. For the poet Goethe, the use of laboratory equipment meant 'torturing of nature, while you should treat it with respect and consideration as a work of art' [12, p. 128] (fig. 2).
Ginkgo Biloba
'Dieses Baums Blatt, der von Osten
Meinem Garten anvertraut,
Giebt geheimen Sinn zu kosten,
Wie's den Wissenden erbaut.
Ist es Ein lebendig Wesen,
Das sich in sich selbst getrennt?
Sind es zwey, die sich erlesen,
Dass man sie als Eines kennt?
Solche Frage zu erwiedern,
Fand ich wohl den rechten Sinn,
Fühlst du nicht an meinen Liedern,
Dass ich Eins und doppelt bin?'
'This sheet of the tree
Entrusted to my garden from the East
Provides a secret sense to feel
Which is a pleasure for those who know.
Is it a vivid being
Divided in itself?
Or are there two
Who might be known as one?
To respond to such questions
I probably found the right sense,
Don't you feel in my songs,
The fact that I am One and also double?'

Helmholtz knew from his own experience as a patient during his younger years, and later as a practising physician, that '[...] at the patient's bed reason alone often is not enough to unravel the complicated tangle of multiple and varied causes of a disease [...], that the law of causality, 


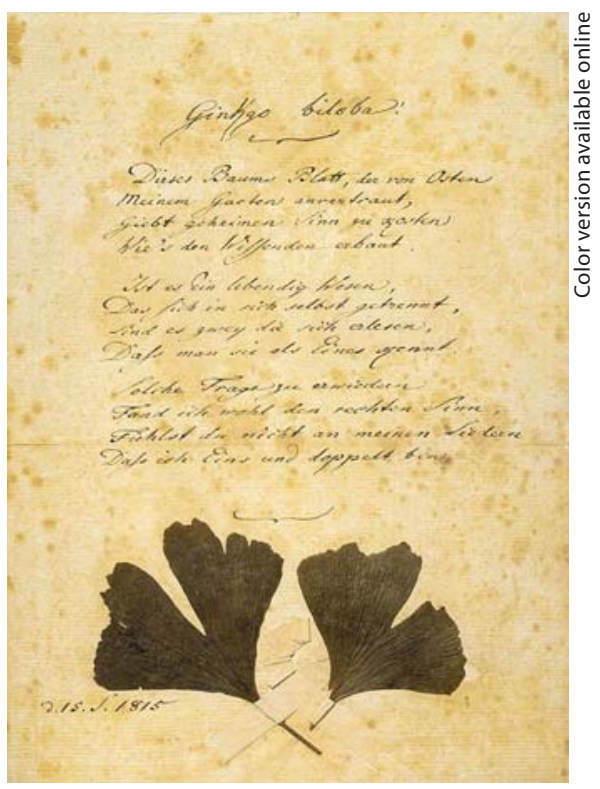

Fig. 2. Goethe's poem Ginkgo Biloba (1815) with two dry leaves of Gingko biloba pressed and added by himself.

which Kant and the physicist so much loved, could not be easily applied to life' [12, p. 47].

Lord Kelvin [1] ended his speech on Helmholtz before the Royal Society with the words:

'Soon after his work on heat in animals [...] followed studies on the speed of transmission of nerve impulses along the sensory nerves, then about the amount of time it takes from the moment, when a person perceives a sensation, until the moment when the decision takes place, i.e. the measurement of speed of transfer along motor nerves to muscles. A few years later he would perform his great work on "Über Tonempfindungen" ("On sound sensations"), which holds a unique position in the literature of philosophy, not only does it deal with the perception of sounds, but at least as much with mathematical and experimental investigations, ranging from the anatomical structure of the ear up to the philosophical foundation of musical art - certainly a wonderful memorial to the genius and the indomitable work power of its author.'

Helmholtz made the esthetics of music the subject of his investigation after a century of neglect, when he wrote: 'Music has withdrawn so far from scientific treatment more than any other art.' Poetry, painting, and sculpture borrow from the world of experience, but music seems to nullify the dissecting of sensations. As an empiricist, he understood the unifying capacity of music theory and esthetics. Music could be understood only as great art linking anatomy, physiology, philosophy and psychology together [15]. Another great work of Helmholtz is his 'physiological optics' [16]. Who is to say which of the two books is the more important, which the more interesting, or the more valuable one? Each has all of these wonderful qualities in the highest degree.

Helmholtz is an excellent guide to spiritual walks in this ambiguous, twilight zone in our history, where reason and artistic intellectual energies come together to such an extraordinary extent in individuals, as this example illustrates [3].

'Without a doubt he was one of the finest feathers in the cap of neurological science in the nineteenth century, an unbeaten technician, theoretical physicist and excellent mathematician, enabled anatomist and physiologist [...] an experienced and enthusiastic connoisseurs of the history of music and musicology' [12, p. 196].

The fundamental change in mentality began earlier than in Helmholtz' times and may be illustrated in an episode involving the 'Philosopher of Sanssouci' and the Bach family: Frederick the Great asked Johann Sebastian Bach about a musical theme which he had composed himself and asked him to improvise fugues in his presence. Johann Sebastian Bach actually did so immediately and with great success. But when the King then demanded that he compose six-part fugues, Bach was somewhat embarrassed, because he found that the theme was not good enough for such a difficult task. This episode marks a fundamental turning point in history: a subject despite all his bows and obeisances could decide that his own artistic will was more important than the command of a sovereign and then act accordingly. Bach went home and put thirteen beautiful variations on an original theme of his own to paper and devoted the work to the King, as if it had been based on the royal theme and under a title which comes close to the English word 'Research': 'Ricercar', short for Regis Iussu Cantio et Reliqua Canonica Arte Resoluta ('That topic provided by command of the King with additions resolved in the canonic style'). This is now known as a 'musical offering' [17].

\footnotetext{
References 1 Obituary Hermann von Helmholtz. Proc R Soc Lond 1896;59:xvii-xxx.

2 Anniversary Meeting. 30th November 1894. Proc R Soc Lond 1894-1895;57:35-59.

3 Kesselring J: Twilight at the birth of modern neuroscience. Brain 2011;134:1571-1574.

4 Benn G: Goethe und die Naturwissenschaften. Zürich, Arche Verlag, 1949.
} 
5 Heidelberger M: Helmholtz' Erkenntnisund Wissenschaftstheorie im Kontext der Philosophie und Naturwissenschaft des 19. Jahrhunderts; in Krüger L (ed): Universalgenie Helmholtz. Rückblick nach 100 Jahren. Berlin, Akademie-Verlag, 1994, pp 168-185.

6 Helmholtz H: Das Denken in der Medicin. 2. neu durchgearbeitete Auflage. Berlin, A. Hirschwald, 1978.

7 McGilchrist I: The Master and His Emissary. The Divided Brain and the Making of the Western World. New Haven, Yale University Press, 2009.

8 Scull A: Left brain, right brain: one brain, two brains. Brain 2010;133:3153-3156.
9 Helmholtz H: Über Goethe's naturwissenschaftliche Arbeiten. Vortrag zu Königsberg 1853. Braunschweig, Friedrich Vieweg, 1896, vol 1.

10 Helmholtz H: Goethes Vorahnungen kommender naturwissenschaftlicher Ideen. Rede in der Generalversammlung der Goethe Gesellschaft zu Weimar am 11. Juni 1892; in Mandelkow KR (ed): Goethe im Urteil seiner Kritiker. Dokumente zur Wirkungsgeschichte Goethes in Deutschland. Teil III: 1870-1918. Munich, Beck, 1979, pp 227-244

11 Hallet D: On the subject of Goethe: Hermann von Helmholtz on Goethe and scientific objectivity. Spontaneous generations. J Hist Philos Sci 2009;3:178-194

12 Meulders M: Helmholtz. From Enlightenment to Neuroscience. Cambridge, MIT Press, 2010.
13 Pearce JMS: The ophthalmoscope: Helmholtz's Augenspiegel. Eur Neurol 2009;61: 244-249.

14 Gruber H, Gruber V: Hermann von Helmholtz: nineteenth-century polymorph. Sci Monthly 1956;83:92-99.

15 Rousseau G: A polymath rediscovered. Nature 2010;467:1039-1040.

16 Helmholtz H: Über die Erhaltung der Kraft. Eine physikalische Abhandlung. Reprint von 1847. Leipzig, Engelmann, 1902.

17 Schneewind U: 'Jede Note an Dich gerichtet!' Musikalische Widmungsgeschichten aus drei Jahrhunderten. Darmstadt, Wissenschaftliche Buchgesellschaft, 2009. 